\title{
Space-time patterns of soil pH in submountain beech ecosystems in the West Carpathians
}

\author{
R. Janík, B. Schieber, E. Bublinec
}

Dr. Ing. Rastislav Janík, Ústav ekológie lesa SAV vo Zvolene, Štúrova 2, SK- 96053 Zvolen, Slovenská republika,e-mail:janik@savzv.sk

Abstract: Janík R., Schieber B., Bublinec E. 2014: Space-time patterns of soil pH and conductivity in submountain beech ecosystems in the West Carpathians. Beskydy, 7 (2): 81-86

The results of $\mathrm{pH}$ values monitoring performed for 26 years (1988-2013) in Štiavnické vrchy Mts (middle Slovakia) are summarised. The accumulative trend of acidifying components of forest soils downwards the soil depth has been confirmed. The $\mathrm{pH}$ values of soil, exposed to a severe airborne pollution load in the past, were in general lower: from 5.42 in the surface humus decreasing to 4.93 at a soil depth of $0.25 \mathrm{~m}$. On the other hand, the $\mathrm{pH}$ values of throughfall and precipitation in open area were comparable. The lower $\mathrm{pH}$ values were found in lysimetric water within the forest stand plot at $0.10 \mathrm{~m}$ depth (4.50 in 2009). The absolute highest $\mathrm{pH}$ were found in the forest throughfall and reached the values of 6.40 in year 1999.The annual dynamics exhibited the highest $\mathrm{pH}$ values in the winter and spring. On the other hand, the lowest values were recorded in summer period.

Keywords: pH, acidification, Štiavnické vrchy Mts, beech ecosystem

\section{Introduction}

The principal and easiest at hand indicator of soil acidity is their $\mathrm{pH}$ and conductivity. Acidification of forest soils belongs to the main factors responsible for significant changes to forest ecosystem diversity in a long term prospect (Bobbink et al. 2010, Maskell et al. 2010). This results in the depletion of cations providing basic nutrients necessary for production and vitality of tree layer (Fenn et al. 2006, Hruška et al. 2001), drop in $\mathrm{pH}$ values and lowering the humus quality (Oulehle, Hruška 2005, Borůvka et al.2005, Bonneau 2005).

The main anthropogenic agents affecting soil acidification are acid deposition and forestry. To understand and control the factors underlying forest stand development means a very complex process, the individual constituents of which may interact in a positive or negative way. The effects of each of these factors can be multiple and simultaneous. The soil properties display more space variation in O horizons than in B horizons, with the latter more influenced by soil-forming processes (Svedrup et al. 1992).

Despite the pan-European decrease in sulphur emissions recorded in the recent decades (Kunca 2008, Pichler et al.2006, Jandl et al. 2012, Zapletal 2006) the soil acidification is still remaining a serious forestry-related and environmental problem. The soil data submitted by 23 European countries demonstrate acid A horizon in $42 \%$ out of the 4532 localities surveyed. In $1.9 \%$ cases, the acidity was found even strong (with $\mathrm{pH}$ soil reaction under 3). It has been revealed that the higher A-horizon acidity was more frequent in areas with higher acidifying load, in soils with extremely weak buffering capacity against acidification, especially in Holland, Finland and Belgium. On the other hand, the highest resistance against acidification was observed in Luxembourg, Slovakia, Hungary, Slovenia, Portugal, Switzerland and Austria (Anonymous 1999). The forest soil monitoring performed by the Forest Research Centre in Zvolen resulted 
in finding out that about one half of the forest plots inspected (from the total of 5843) was, in terms of their soil reaction and base saturation, in the buffer zone aluminium and the soils on almost $10 \%$ of them were identified as extremely acid (Kanianska 2007).

The drop in soil acidity and the nitrogen deposition in context of the contemporary climate change will limit the silvicultural function of forest communities. Trapping carbon and nitrogen, these communities act as an effective filter and a cleaning layer for water flowing through them. Storing and accumulation of nitrogen in soil can mitigate negative impacts of the climate change.

The aim of this paper was to show the trends in $\mathrm{pH}$ and conductivity values in the beech stand and open plot in the Štiavnické vrchy Mts (the West Carpathians Mts.). This site, along with site in Kremnické vrchy Mts. will serve as model localities to investigate the impact of airborne pollution load.

\section{Methods}

\section{The Study Area}

The Štiavnické vrchy Mts. are volcanic mountain massifs belonging to the Slovenské Stredohorie Mts. Intensive agriculture, industry and landscape urbanisation are its typical feature. The set of study plots (stands plot and open plot) is located in NW part of the Štiavnické vrchy Mts., middle Slovakia $\left(48^{\circ} 35^{\prime} \mathrm{N} ; 18^{\circ} 5 \mathrm{l}^{\prime} \mathrm{E}\right)$. Forest stands are formed by beech (Fagus sylvatica L.) of the age 110 years with the original stocking of 0.9. The elevation is $470 \mathrm{~m}$ a.s.l., slope reaches $20^{\circ}$. The area of the study plots belongs to the moderately warm district with mean annual precipitation of $750 \mathrm{~mm}$ (min. $431 \mathrm{~mm}$, max. 1,020 mm). The average air temperature ranges from 8.0 to $8.5^{\circ} \mathrm{C}$, while during the growing period the average air temperature is $14.5-15.5^{\circ} \mathrm{C}$ (Kellerová 2005). Geological substrate are rhyolite tuffs and soil type is luvic cambisol.

The Štiavnické vrchy Mts. were strong affected by pollutants from the regional sources (production of aluminium, power industry, transport, waste dump). The main contaminants were oxides of fluorine, sulphur and nitrogen, heavy metals as arsenic and cadmium, ozone and particulate matter. The long-time increased input of these pollutants from air to the ecosystems of the Štiavnické vrchy Mts. caused the changes in the ecological conditions. This situation led to the negative quality of the beech stands in the study region. The worst effect for the beech forests had sulphur dioxide $\left(\mathrm{SO}_{2}\right)$ and fluorine. The region of the Žiarska kotlina basin was regarded for many years as an area with the most polluted environment in Slovakia. For this reason in the 1990's this area was classified to the II.-III. degree of exhalation. Since the end of the 1990's the amount of the pollutants has been decreasing rapidly because of the modernization production processes and more strictly legislation. The concentration of fluorine was cutting down on the tolerable level $1 \mu \mathrm{g} . \mathrm{m}^{-3}$ (Urminská et al. 2000).

The lysimetric water was sampled into plastic collectors $\left(1000 \mathrm{~cm}^{2}\right)$ in three different soil horizons. The first set is installed in the layer $\mathrm{H}_{00}$, i.e. the surface horizon (organic layer), the second at a depth of $0.10 \mathrm{~m}$ below the soil surface (upper mineral layer) and the third at $0.25 \mathrm{~m}$ below the surface (lower mineral layer) (Kukla 2002).

Atmospheric precipitation and throughfall water were collected into funnels issuing in closed collectors $\left(660 \mathrm{~cm}^{2}\right)$. The collectors were spaced regularly throughout the stands and the adjacent open plots (by 10 pcs on each). The representative samples were obtained by mixing the water from all collectors in the forest stands and open plots. In both cases, the samples were collected at regular time intervals and after each relevant precipitation episode (Lindberg, Turner 1988).

The $\mathrm{pH}$ values was measured potentiometrically using a WTW INOLAB 720 pH meter (Weilheim, Germany).

The data were processed using the statistical program Statistica 7. Student's t-test for dependent variables was used to assess the statistical significance of differences between the soil horizons.

\section{Results and Discussion}

The mean $\mathrm{pH}$ value in the surface humus layer was 5.42, with the maximum of 6.06 recorded in 2001, and minimum of 4.82 recorded in 1982. These values indicate an almost strong acid environment. The variation range was only 1.24 , and also the variability reached 7.01\%. was relative low (Tab. 1).

The Fig. 1 shows a distinct increasing trend in $\mathrm{pH}$ values, demonstrating improving conditions for the locality inspected. This fact has also been confirmed by the low values of standard deviation and standard error 
Tab. 1: Descriptive statistics of pH in the Štiavnické vrchy Mts (Western Carpathians Mts.) in years 1988-2013.

\begin{tabular}{|c|c|c|c|c|c|}
\hline Lysi meter & F00 & $\overline{\text { F10 }}$ & $\overline{F 25}$ & $\begin{array}{c}\text { Open plot wet } \\
\text { deposition }\end{array}$ & $\begin{array}{c}\text { Forest } \\
\text { through fall }\end{array}$ \\
\hline \multicolumn{6}{|c|}{$\overline{\mathrm{pH}}$} \\
\hline Mean & 5.42 & 5.14 & 4.93 & 5.86 & 5.80 \\
\hline Minimum & 4.82 & 4.50 & 4.58 & 4.85 & 4.76 \\
\hline Maximum & 6.06 & 5.57 & 5.35 & 6.37 & 6.40 \\
\hline Range & 1.24 & 1.08 & 0.77 & 1.51 & 1.64 \\
\hline $\begin{array}{l}\text { Coefficient } \\
\text { of variation }\end{array}$ & 7.01 & 23.93 & 3.65 & 6.45 & 7.24 \\
\hline $\begin{array}{l}\text { Standard } \\
\text { Deviation }\end{array}$ & 0.38 & 1.23 & 0.18 & 0.38 & 0.42 \\
\hline Standard Error & 0.07 & 0.05 & 0.03 & 0.08 & 0.09 \\
\hline
\end{tabular}

$\mathrm{F}_{00}-\mathrm{F}_{25}$ Lysimeter in the Forest

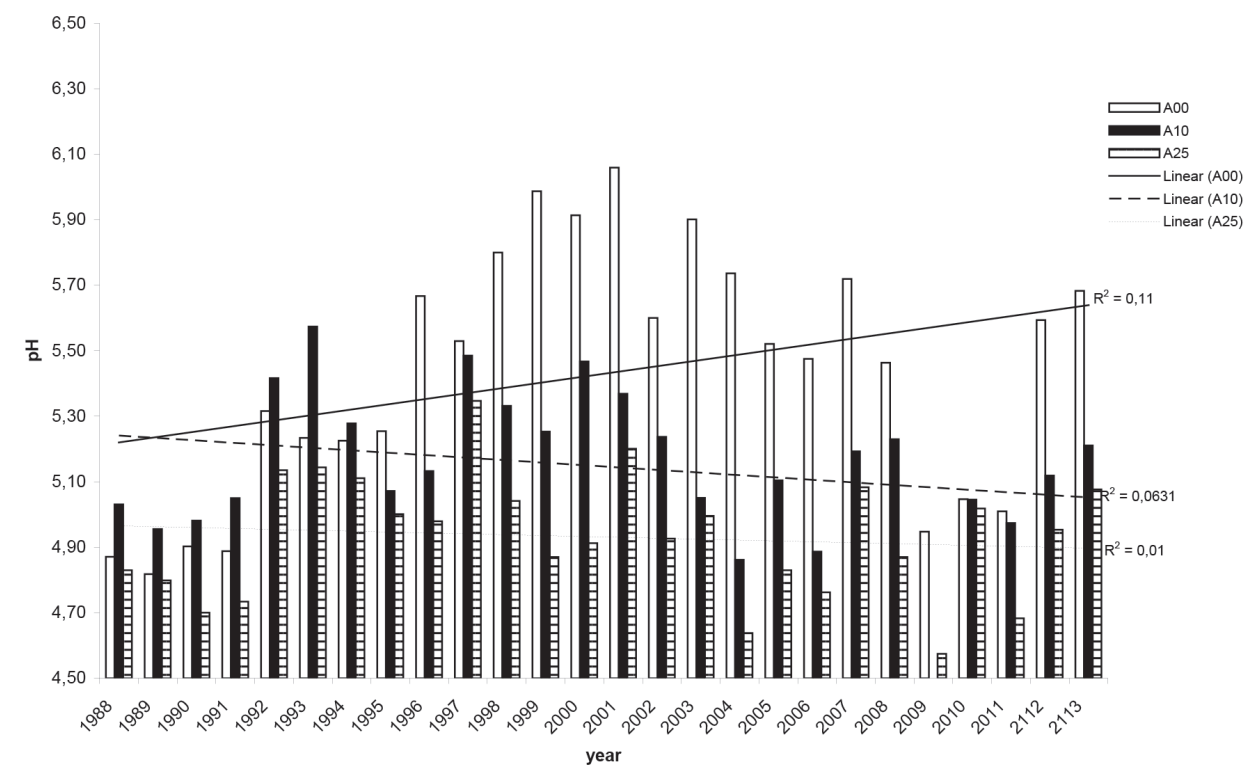

Fig. 1: pH values of soil horizons in the Štiavnické vrchy Mts in the years 1988-2013.

The situation at the depth of $0.1 \mathrm{~m}$ below the surface was a little different. The mean $\mathrm{pH}$ value was lower (5.14), and the strong acidity was also implied by minimum values (4.50) recorded just in 2009. The maximum, representing 5.57 was recorded in 1993. The trend testifies to a moderate decrease in $\mathrm{pH}$ values. The variability was almost $24 \%$. (Tab. 1).

The depth of $0.25 \mathrm{~m}$ manifested the lowest mean $\mathrm{pH}$ value (4.93), with the minimum of 4.58 recorded in 2009, and a maximum of 5.37 recorded in 1997. The trend line demonstrated an increasing tendency. For this depth, all statistical characteristics had the lowest values (Tab. 1). Slight influence of stand composition and canopy structure was also discernible on $\mathrm{pH}$ values of the throughfall.

The $\mathrm{pH}$ patterns of the precipitation on the open plot and the throughfall were very similar (Tab. 1, Fig. 2).

Somewhat higher mean values were recorded on the open plot (5.86 compared to 5.80 in the stand). In both cases, the trend lines are decreasing. Mindáš (2005) observed the following 


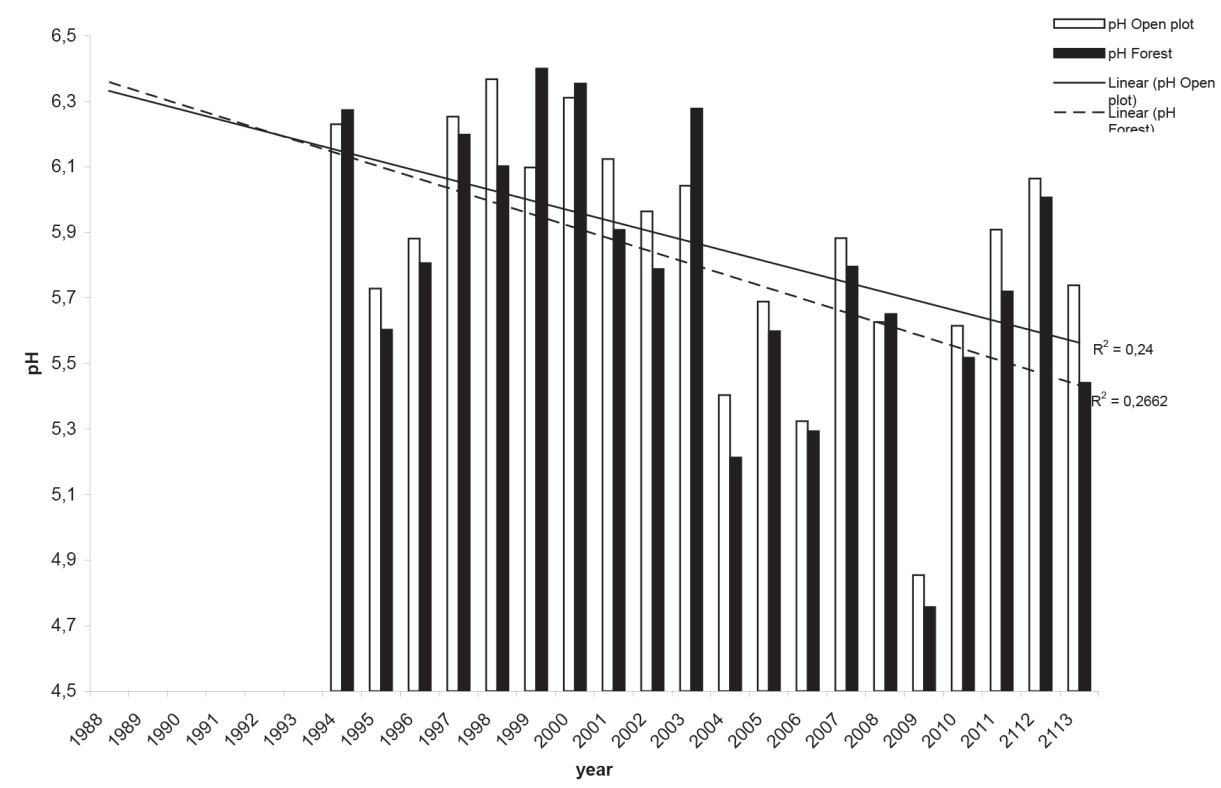

Fig. 2: pH values at the open plotwet deposition and in the forest throughfall in the Štiavnickévrchy Mts in the years 1988-2013.

changes in $\mathrm{pH}$ values in the throughfall, compared to the vertical precipitation above the stands: moderate, statistically insignificant ( $\alpha$ $=0.1$ ) increase after falling through a canopy gap, a negligible change after falling through beech crowns and a statistically significant $(\alpha=0.01)$ shift to more acidity after falling trough spruce canopy.

Mihálik et al. (1993) studying the chemistry of stemflow (precipitation water flown to the ground along tree stems) in the locality Mláčikin the KremnickévrchyMts. (850 ma.s.l) report the following annual mean values of the active reaction for beech stemflow: 4.47 in 1986, 4.40 in 1987, and 4.96 and 4.72 in 1990 for 130 year-old trees and 15 year-old trees, respectively. The $\mathrm{pH}$ value observed in the same year on an open plot was 4.92. A more distinct difference in $\mathrm{pH}$ values between the original precipitation and stemflow on 15-year-old beech trees has been reported by Gower et al. (1995) from south England (1984-1985): 5.2 on an open plot and 3.3 in the stemflow. This decrease could be due to a higher portion of acid anions of marine origin as well as due to the very small share of beech stemflow representing only less than $1 \%$ of the precipitation fallen on the open ground.

The $\mathrm{pH}$ values can also depend on the total precipitation sum, as abundant rainfall can cause leaching of base elements and shifting $\mathrm{pH}$ values towards the acid range (Skrzypek et al. 2008.

\section{Conclusion}

The accumulative trend of acidifying components of forest soils downwards the soil depth has been confirmed in two beech ecosystem differing in their pollution history, where the mean $\mathrm{pH}$ value at $0.25 \mathrm{~m}$ was 4.25 . The corresponding values in the Kremnické vrchy Mts, relatively pollution-free, were 6.25 in open area and $6.06 \mathrm{in}$ beech forest stand.

The $\mathrm{pH}$ values in throughfall and in lysimetric water were lower than the $\mathrm{pH}$ values in free precipitation. The opposite was true in the Kremnické vrchy Mts.

In both study localities, the forest stand's influence on the throughfall $\mathrm{pH}$ was statistically insignificant.

\section{Acknowledgement:}

This work was supported by the Scientific Grant Agency of the Ministry of Education of the Slovak Republic and the Slovak Academy of Sciences (Projects No. 2/0041/13, 2/0053/14, 2/0089/14 and 2/0113/12). We also acknowledge D. Kúdelová for preparing the English text. 


\section{References}

Anonymous, 1999: EEA: Environment in the European Union at the turn of the century. Soil degradation, $446 \mathrm{p}$.

Bobbink, R., Hicks, K., Galloway, J., Spranger, T., Alkemade, R., Ashmore, M., Bustamante, M., Cinderby, S., Davidson, E., Dentener, F., Emmett, B.,Erisman, J.W., Fenn, M., Gilliam, F., Nordin, A., Pardo, L., De Vries, W. 2010: Global assessment of nitrogen deposition effects on terrestrial plant diversity a synthesis. Ecological Applications, 20: 30-59.

BONNEAU, M. 2005: Evolution of mineral fertility of an acidic soil during a period of ten years in the Vosges Mountains (France). Impact of humus mineralisation. Annals of Forest Science, 62: 253-260.

BorŮVKa, L., MLÁdKOVÁ, L., DrÁBEK, O., VAšÁt, R. 2005: Factors of spatial distribution of forest floor properties in the Jizerské Mountains. Plant, Soil and Environment, 51:316-321.

Fenn, M. E., Huntington, T. G., McLaughlin, S. B., EAgar, C., Gomez, A., Cook, R. B. 2006: Status of soil acidification in North America. Journal of Forest Science, 52: 3-13.

Gower, C., Rowel, D.L., Nortcliff, S., Wild, A. 1995: Soil acidification: comparison of acid deposition from the atmosphere with inputs from the litter / soil organic layer. Geoderma, 66: 85-98.

HrušKa, J., Cienciala, E., MoravČík, P., Navrátil T., Hofmeister, J. 2001. The long-term acidification and nutric degradation of forest soils (in Czech). Lesnícká práce, 80 (12): 24-32.

Jandl, R., Smidt, S., Mutsch, F., Fưrst, A., Zechmeister, H., Bauer, H., DirnböcK, T. 2012: Acidification and Nitrogen Eutrophication of Austrian Forests soils. Applied and Environmental Soil Science, 28: 1-9.

KANIANSKA, R. 2007: Pôda ako zložka životného prostrediav SR k roku 2006. SAŽP: 45.

KellerovÁ, D. 2005: The air pollution in the surroundings of an aluminium plant. Ekológia (Bratislava), 24 (1): 122-128.

KuKLA, J. 2002: Variability of solutions percolated through cambisol in a beech ecosystem. Ekológia (Bratislava), 21: 13-25.

KuncA, V. 2008: Atmospheric deposition and critical loads in a climax oak forest in the Stiavnické vrchy Mts. Folia Oecologia, 35: 15-19.

Lindberg, S., Turner, R. 1988: Factors influencing atmospheric deposition, stream export in forested watersheds. Water, Air and Soil Pollution, 39: 123-156.

Maskell, L.C., Smart, S.M., Bullock, J.M., Thompson, K. , Stevens, C.J. 2010: Nitrogen deposition causes widespread species loss in British Habitats. Global Change Biology, 16: 671-679.

Mihálik, A., Krajčovič, P., Škvarenina, J. 1993: Zmeny kvality podkorunových zrážok v závislosti od druhu a veku drevín. Lesnický časopis - Forestry Journal, 39 (2): 85-99.

MINĎÁš, J. 2005: Characteristics of the precipitation and soil water quality in the mature mixed forest stand (fir-spruce-beech) of midmountain region Pol'ana - I. acidity and acidifying components. Lesnický časopis - Forestry Journal, 51 (2): 179-197.

Oulehle, F., HrušKa, J. 2005: Tree species ( $P i$ cea abies and Fagus sylvatica) effects on soil water acidification and aluminium chemistry at sites subjected to long-term acidification in the Ore Mts., Czech Republic. Journal of Inorganic Biochemistry, 99 (9): 1822-1829.

Pichler, V., Bublinec, E., Gregor, J. 2006: Acidification of forest soil in Slovakia-causes and consequences. Journal of Forest Science, 52 (Special Issue): 23-27.

SkrzypeK, G., Akagi, T., Drzewicki, W., JedrySEK, M. 2008: Stable isotope studies of moss sulfur and sulfate from bog surface waters. Geochemical Journal, 42: 481-492.

Svedrup, H., Warfring, P., Frogner, T., Hæøya, A. O., Johansson, M., Andersen, B. 1992: Critical loads of forest soils in the Nordic countries. Ambio, 21: 348-355.

Urminská, J., Khun, M., Jurkovič L'. 2000: Risk of influence of certain non desired elements in the environment of the Žiarska kotlina, Basin and their relation to the health state of the local population (in Slovak). In: Monitorovanie a hodnotenie stavu životného prostredia III. TU, ÚEL SAV Zvolen, 165-173.

Zapletal, M. 2006: Atmospheric deposition of nitrogen and sulphur in relation to critical loads of nitrogen and acidity in the Czech Republic. Journal of Forest Science, 52 (6): 92-100. 
